\title{
The Lessons of Kola Nut in Searching for Nigeria's Unity
}

\author{
Ifeyinwa Cordelia Isidienu \\ http://dx.doi./org/10.4314/ujah.v19i2.7
}

\begin{abstract}
Unity is the state of being one undivided entity. Nigerian society has different ethnic groups which is joined together to become a single nation. Right from the onset, unity has eluded the nation because of her diversified cultural backgrounds. In Igbo culture, kola nut has various parts which have joined together as one single whole. This paper therefore, explores the functions of Igbo kola nut in the unification of the Nigerian nation. It looked at the social, political, religious and economic functions. Related literatures were reviewed to help enhance the study. A descriptive survey research approach was adopted. The instrument for data collection was unstructured questionnaire. It was discovered that Igbo kola nut is well respected in all the Igbo communities. It is accorded recognition in all celebrations and serves the role of unifying the Igbo people. The paper recommends the adoption of the roles of kola nut in all the events of the nation for her oneness.
\end{abstract}

\section{Introduction}

Igbo kola nut holds an important position in the Igbo cultural life. Considering the size, one may tend to ignore it but the role it plays as a unifying factor cannot be over-emphasized. Igbo kola nut performs political, social, economic, and religious functions. These basic functions are made manifest during the presentation, blessing, breaking, distribution and celebration of the kola nut as a whole. According to Igbo (2012:49) "The generality of Igbo nation 
recognizes the reference and valued essence of kola nut in their life." Igbo people believe that whoever brings kola nut brings life. Life must be protected and people must be harnessed for life to be meaningful. For the Igbo, people must be unified as exemplified in kola nut with various parts yet a whole entity.

Unity is re-enacted each time kola nut is celebrated or presented on different occasions. It is however, necessary to explore the various stages found in kola nut celebration which has helped to unify Igbo people. The functions they perform will also be x-rayed. The functions if however adopted by Nigeria will help her to become a more unified nation.

\section{Igbo Kola Nut Explained}

Different authors have written on kola nut. It is however noted that there are different species of kola nut, kola acuminata, or atrophora, kola alba and kola nitida. Ekhosuehi (2015) expresses that "Customarily kola is a tree that originated from West Africa. There are mainly three varieties which are kola Nitida, kola Acuminata and kola Caricifolia." $\mathrm{He}$ also stated that kola Acuminata originated from Benin kingdom and mostly found in southern Nigeria. Igbo kola nut (oji Igbo) is known as kola acuminata, the seed normally has up to seven cotyledons. It is a special natural fruit with a peculiar traditional-cultural function and recognitions. It is a sign of love and peace, a medium of dialogue with God, a symbol of Igbo unity. It is utmost important to Igbo and serves as a sign of hospitality to visitors, used to start any social gathering and ceremonies, used for prayers, a token of joy and stands for equity. It shows acceptance to a visitor, a unifying seed and also economically viable. It is also used to appeal to God, eat as a stimulant and also serves as a means of evangelizing the rich culture and dynamic tradition of Igbo man. Igbo kola nut is 
mainly used for occasions and ceremonies, served at burials; used in peace making missions and various other purposes.

Hausa kola nut (oji Awusa or gworo) ,kola nitida is found almost everywhere in west Africa. It has two cotyledons. Another type of kola that is very bitter, with one cotyledon is kola caricifolia. However the focus of this study is Igbo kola nut which is reddish in colour, with many cotyledons. According to Igbo (2012:50),

A typical and fully developed Igbo kola will bear not less than three cotyledons, and most often not more than seven or eight. Another specie called "oji ugo" of the same size and shape but with yellow colour is of high cultural value. This brand of kola nut is often rare and symbolizes royalty and purity.

Eagle kola nut (oji ugo) as has been observed, is normally kept for special visitors and purposes. Kola nut grows from its seed. It belongs to cotyledon's family. Kola nut without cotyledon (oji ifilifi or oji ogbi) is not eaten in Igbo culture areas. One with two cotyledons (ibe abuo) cannot be eaten by titled men and cannot be used in any occasion. Three cotyledon kola nuts (ibe ato) represents good omen. Igbo (2012) also states that the "Three lobes of Igbo kola nut is often a symbol of "ikenga", personified individual achievement and a sign of good omen." Kola nut that has four cotyledons represents the Igbo four market days. Furthermore, five cotyledons symbolize procreation, wealth and good tidings. Six symbolizes bad luck or bad omen. It is not eaten or one of the lobes may either be discarded and the rest will be eaten. Opata (1998:100) noted that "Kola nut with six lobes does not have special regard because the number six is not associated with any symbolism among the Igbo." He pointed out that 'three,' 
'four,' 'five,' and 'seven' have great symbolic significance among the Igbo. Kola nut can also have seven or eight lobes. It is rare to be found and was highly valued. It shows fullness of life, wealth, peace and progress. In most cases, ceremonies are performed before it is eaten. Each kola nut has a tiny central axis which holds and unites the cotyledon. This part is given to the ancestors whenever kola nut is broken. According to Ekwunife (1990) "The tiny central lobe symbolizes the presence of the invisible world with its beings in the midst of the visible. It is this presence that makes the Igbo world thinks in a perpetual interaction between these two worlds."

The uniting force is the unseen. Igbo people recognize this relationship and would not joke with the customs of the kola nut. Igbo (2012: 51) was right when he states that,

As one of the ritual elements in Igbo culture, the Igbo kola nut expresses, communicates, and unites the people's ideas of fraternity, acceptance, achievement, productivity, wealth, joy and sorrows of every family, village and clan, so also the unity and diversity of the Igbo world; hierarchy, authority, royalty and purity, wholeness of human beings, fullness of life and perpetual presence of the spirits among men.

Kola nut although with many lobes, yet joined together as a single whole is full of symbolisms. The meanings continue to unfold in the lives of the people as they are made stronger and united each day, as they perform the rituals of kola nut. The presentations, blessings, sharing, eating, are all binding forces. 


\section{The Ceremony of Kola Nut}

Actually, kola nut is a seed that has a very high regard among the Igbo. Because of its importance it has taken a place in the live of every Igbo person. However certain ceremonies must be performed before one eats a presented kola nut. It must follow a sequential order i.e. Presentation of the kola nut, blessing of kola nut, breaking of kola nut and sharing of kola nut.

Kola nut is highly placed and valued in Igbo culture area. It is the first thing given to a visitor, deities and a starting point of any cultural event in Igbo land (Ekwealor, 1998:38). Kola nut was held almost as sacred and is the very first thing which is presented to a visitor familiar or unfamiliar, relatives or non-relatives before any other thing or discussion on any subject. In the same way, it is the first thing to be presented to an idol or god before any other offering or request is made (Ogbalu, 2006:71). It is obvious that kola nut does not discriminate against people. It can be used to serve both a known and unknown visitors and relative. Presenting it signifies open mindedness, acceptance, happiness, unity and so on. Kanu (2015: 82) states that "Kola nut among the Igbo is a symbol of life, peace and goodwill." Kola nut is the first thing an Igbo man will serve his visitor. If however a visitor was not served kola nut and his host does not acknowledge the fact of not presenting a kola to him, for instance, pleading with the visitor that he did not have kola in the house. The visitor will take it that, he was not accepted or welcomed.

Blessing of the kola nut is another important aspect of this custom. It should be noted that if the kola nut is presented in the gathering of people, it is the most elderly man or a titled man in their mist; should be the one to bless the kola nut. As Orji (1999) rightly notes that 
The respect accorded to kola nuts accounts for the honour also done to it during breaking by asking the most elderly man present to do the breaking. He in turn blesses it, prays for the good health, long life and prosperity of everyone

This is a period of selflessness. Prayers are made on behalf of everybody and for the entire community. Everybody present with one accord, one mind and one spirit would answer "iseee," in affirmation, meaning Amen, let it be so. It should be noted that every family head must pray with kola nut every morning for thanksgiving, protection and prosperity.

The breaking of the kola nut follows immediately after the blessing. That should also be done by the host or the elderly man that blessed the kola. In some communities in Igbo land, after blessing the kola the youngest male among the group might be asked to break the kola, this was seen as a kind of running errand for the elderly. The kola nut must be broken in such a way that it would reach everybody present.

The kola nut is then shared to everybody, at the event of sharing, and if it was found that kola nut could not reach to everybody; it will further be cut into smaller pieces. Ekhosuehi (2015), writes that kola nut sharing offers community mutual trust, mutual self relationship, mutual listing, mutual help, equality, personal freedom and creativity. To add to this, Opata (1998:117) made it clear that "One lesson which kola sharing practices in Igbo land teach is that life is full of conflict and that given patience and explanation for the rationale of action, such conflict can easily be resolved." At the point of sharing the kola nut, people may disagree. When such is the case, explanations are made and peace 
is returned at once. Even the same piece of kola nut that brought disagreement would be shared equitably among the people.

\section{Functions of Kola Nut}

It was observed that kola nut performs a lot of functions in Igbo cultural life. The significance of kola nut in unifying people cannot be over-emphasized. The functions served were mainly social, political, religious and economical.

\section{Social Functions}

In the social functions of kola nut, it plays a very important role as people come together. Kola is the first port of call in receiving visitors in Igbo land. It shows the value and respect one has for his neighbour. Ukaegbu's (2005:89) view is that "He who refuses to bring out kola, denies not only the kola but also the blessing and thanksgiving that go with it." Prayers of thanksgiving are made to God each time kola nut is brought. Also prayers are sought for God's favours, guidance and protection. People express their feelings, exchange pleasantries, know themselves better and have connections with each other. Igbo kola nut is the same all over the Igbo land, it also have the same meaning. With this in mind, therefore whatever that is acceptable or not acceptable in one part of Igbo land is also the same in other parts of the land. This existing relationship is their secret of communal living.

Ukaegbu (2005: 155) observes that "Igbo kola nut expressed, communicated and unified the people's ideals of fraternity, acceptance, achievement, productivity and wealth, joy, sorrow; of every family, village and clan; unity and diversity of the Igbo world" Kola nut creates an opportunity for good relationship and acceptance among the people. Ukaegbu (2005:90) further affirms that "Kola nut opens and binds people together." Mayaki 
(2011) discovers that kola nut as a "Symbol of hospitality, friendship and respect is presented to guests at important social events such as wedding, funerals, and infant naming ceremonies."

It was however gathered that the relationship among the ethnic groups in Nigeria is a case of mistrust and lack of confidence among and between them. This was as a result of their differences in culture, language and tradition. However since the major ethnic groups in the nation have an idea of kola nut; Kola nut therefore offers an opportunity for good relationship and acceptance among the people.

Apart from the National flag, most countries of the world have something to identify them. However, identification mark is more prominent in homogeneous countries. Nigeria being a heterogeneous nation could not claim any reference item or something they have in common. The implication is ethnic pride, selfishness and disagreement. Since this is the case with Nigeria with huge population and diverse ethnic groups, it becomes apparent to source for a common ground of interaction, which could be found in Igbo kola nut.

Research findings have shown that in Nigeria, most marriages are not complete until kola nut is shared between the couple and their parents. Also they are a common staple in bride's dowry and during weddings they are served to symbolize the couple's ability and willingness to heal differences in their marriages and always help each other CULLED FROM THE INTERNET. However, Nigerian citizens gather together in various activities such as sporting, political rallies, cultural festivals, children's day, workers' day, meetings and host of other events. If the meaning attached to Igbo kola nut be adopted during such events, people will learn to see other people from other ethnic 
groups as brothers and in so doing the spirit of brotherhood will be upheld.

This will be made possible by enacting a legislation mandating the senate, House of representative and the State Houses of Assembly to adopt the use of kola nut in praying before the commencement of their respective meetings. Since the Igbo kola nut seeks to play a cohesive role, hospitality and acceptance in the society, it should be highlighted and projected to other ethnic groups within the Nigerian nation.

\section{Political Functions}

After the presentation of kola nut, it is passed round for everyone to see and each representative of village, clans, towns, divisions or states would take one kola nut for his people. No one is neglected, ignored or intimidated. Equity is the watch word. It is also shared according to seniority. Nwachukwu (2015) claims that "Among the Igbo people of Nigeria, kola nut plays other important cultural functions." He continued, "Because of the mythical and legendry history of origins and migrations that shape the history of many ethnic constituents of the country, kola nut is used to trace seniority." In addition Opata (1998: 115) reaffirms that

The first remarkable thing about the sharing of kola nut is that it brings about the pattern, and if one inquires, the logic of traditional power sharing of a community ... kola sharing practices in Igbo land depict the list of seniority of members present.

This example drawn from kola nut manifests in all aspects of Igbo man's life. Instances are their mode of leadership, inheritance, sharing of land and so on. An Igbo man does not accumulate wealth for his selfish ends, whatever he does or wherever he goes he does not forget his home or his family and background. Each 
time they come together the ritual of kola nut must be performed. With that the spirit of oneness, peace and patriotic spirit were established among kinsmen. The way kola nut is passed and shared shows the spirit of consensus. Every one present must agree on the manner and mode of sharing otherwise people will disagree. Osuji (1998: 37) supporting the idea affirms that "Kola nut symbolizes peace, respect and goodwill."

It was however observed that the political situation in Nigeria is that of uncertainty and near anarchy. The situation is currently terrible as a result of high level of corruption, tribalism in political appointment and lack of federal character in employment or enrolment into federal institutions and agencies. The situation is that of suspicion and feeling of domination by some Nigerians over others. Opata (1998:105) insists that democracy is essentially a "Free exercise of opinion, the way of the majority, equity and rule of law. It attempts to ensure as an institution that the individual has his share of the societal benefits and provisions." He added, "If this is the essence of democracy, then the oji in Igbo land is a veritable symbol of democracy."

Igbo kola nut is fairly shared, and could this be adopted by Nigeria government in the sharing of national cake, each ethnic group and their states would have their representatives in national issues. What is available would be shown to every group and shared equitably. Everything owned in common such as job opportunities, admission into unity schools and federal institutions, mineral resources and many others should be shared equally just as it is observed during the sharing of kola nut. This will go a long way in perpetuating patriotic spirit, peace and oneness in the country. On this note Opata (1998:117) suggests that

May be Nigeria needs the lesson embodied in kola practices among the Igbo: lesson of mutual respect for the 
opinion of others, lesson of reverence to elders, lesson about hospitality, lesson about the importance of dialogue, lesson about conflict negotiation, the spirit of tolerance and forgiveness, and the spirit to face the future with an open mind.

\section{Religious Functions}

In Igbo culture area, kola nut serves the religious needs of the people. It is a veritable means of communicating with the ancestors. Kola nut is used to offer prayers on behalf of the people, that they may be guided and protected in their daily affairs. Nwachukwu (2015) referring to a research work he carried among the Igbo people of Nigeria states that,

For Timothy Nnubia, an 80 year old Igbo man "kola nut is our prayer book. We wake up to pray with kola nut and use it to invoke the spirit of our ancestors. We also use it to appeal to the God of heaven to guide us in our daily activities. After our petition, we break it and eat, and if there is palm wine or gin, we drink to wash it down.

However in the present time kola nut is also presented in a Christian manner. In such occasions a Reverend Father, a Pastor or an elder in the church could be called upon to pray over kola nut in order to bless it, bless the people and pray for the community. Mayaki (2011) observes that traditionally "Kola nut is regarded as a sacred nut used to communicate with the gods, it was chosen by the elders as the head or king of all seeds." Kola nut acts as a communicative agent and as an intermediary between the people and the gods. It is therefore the first thing to be presented in every occasion. Ibeabuchi (2013:2) discovers that, 
Among Igbo Africans, the aspect of communal celebrated with kola nut which is both a spiritual and physical of unity. The excommunicated or socially stigmatized does not partake of the kola. A condition of admittance is igba oriko a banquet of togetherness, a celebration indicating that the ostracized or the excommunicated person is now free can enjoy the common wealth in sharing love ...in such communal celebration of brotherhood, the members of the community partake spiritually hence the belief that everything is done in respect of the ancestors whose blessings are sought before commencing any activity.

The state of religion among the three major ethnic groups in Nigeria is threatening. Religion has not helped enough in addressing the chronic and heart-throbbing differences in religious denominations of Christianity, Islam and traditional. It is believed that Igbo kola nut performs religious functions and can be adopted by Nigeria in the same way it is used for prayers to deities, spirits and supernatural for the gift of moral decorum, socio-political sanity and economic survival of society. Also to appease the spirits, invoke God for enthronement of peace, good health, unity in human race and posterity.

Nwachukwu (2015) affirms that kola nut is "Regarded as a sacred nut used to communicate with the gods." He stated that it is used as a mediating factor in many ways. He continued, in Nigeria, nothing is said at any event without the presentation of kola nut ritual, it is the first thing to be presented on the occasion of birth, death, marriages, divorce, political rally, inaugurates political rally and sanctifying the ground for ordination of priests and invocation of the gods. It is doubtful however, if the ritual of kola nut is being performed at every event in Nigeria; if that is the case; things could 
have been changed for the better. These points to the need to adopt the religious functions of kola nut in its fullness, in order to allow God direct the affairs of the nation.

\section{Economic Functions}

Kola nut also serves economic functions. It is an important income generating product and therefore a vital item in the Igbo economy. Igbo people plant and also buy kola nut which they use in virtually every occasion. They therefore produce, buy and sell kola nut to meet the needs of the populace and as a means of livelihood. Opata (1998:166),indicates that "At economic level, it is discovered that kola owing and sharing practices are beneficial to some people." He continued,

Among Nsukka people, kola in the traditional homestead, that is the ancestral home from where the members of a clan started to disperse, is owned collectively and held on trust for them by the oldest person in the clan. Since kola is a major means of income in many rural Igbo communities, it is ideologically supportive of those who are so old that they cannot adequately take care of themselves.

Kola nut is cultivated, sold, used for dying clothes; it is also used as drugs and for curing of sleeping sickness. It was however observed that mono-economy can crumple a nation. Diversification of economy is the best way to survive. Nigeria should as a matter of fact pay particular attention to agriculture. They should diversify their economy and explore other viable sources of income like the cultivation of kola nut in large scales. Kola nut can be very important in boosting the Nigeria economy as industries will use it for dying clothes as well as export the commodity for revenue generation. 


\section{Unifying Functions}

Kola nut also performs unifying roles. Ukaegbu (2005:256) notes that "Unity means togetherness for good or bad." He affirms that "There is none that will deny that disunity weakens." Igbo kola nut has different lobes yet unified as a whole. Igbo people were also diversified yet they are one as they re-enact the custom of kola nut all the time. Apakama (2012:39) noticed that,

The kola nut has various lobes or pieces fused together without physical force binding them together. The nut remains like that until an external force dismantles the lobe into pieces. The Igbo world is exactly manifested in like manner as the kola nut. The Igbo people believe in living together and they enjoy harmonious life. They are their brother's keeper and this notwithstanding, there could be disagreement among them if an external force, for instance back biting, and gossips, envy from enemies of progress; anger and hatred are noticed. If these external force are not controlled and contained the Igbo world would scatter.... The kola nut example must be a focal point.

In matters of disagreement and enmity, kola nut is used for peacemaking and settling of cases. If people living together do not trust themselves, unity will be hard to come. Ukaegbu (2005:87) affirms that "The kola nut brought some trust amongst people. Its major contributions are ascertaining how people live and believe, what they accept or respect and how they secure trust. This went further to form basic community of trust." Trust breeds unity and with that any group of individuals can have a meaningful development. Ekhosuehi (2015) emphasizes that "Kola nut is 
precious, that it splits neatly into parts and perhaps for this reason it is a symbol of friendship and unity."

To a large extent Nigeria is not united. The cankerworm of ethnicism and nepotism has dealt great blow to the nation. It was observed that Nigeria is not united going by the threats, waves of insecurity occasioned by the 'Boko Haram', MASSOB Indigenous people of Biafra (IPOB) and so on. Since Nigeria is made up of three major ethnic groups, this implies different languages, cultural backgrounds, ideas, interests, expectations, worries and so on. However, sets of interest are likely to clash as people come together for deliberations as a nation. On the other hand kola nut has much unifying factor, since it is a seed with many parts yet united, that is also the spirit of an Igbo man, 'Igwe bu ike'. If other Nigerians could be persuaded to believe in its spiritual use, it will be to an utmost advantage to the nation. Nwachukwu (2015) declares that whoever brings kola nut brings life; the implication is that kola nut implies the establishment of love and trust. He continued,

That is why it is believed that whoever partakes in the sharing and eating of kola nut with one has become one's friend and has entered into an oath of preservation of life with one. In this sense kola nut becomes a communion food; a feast of love, trust and togetherness.

The unification should be, since the three major tribes are tied to the knowledge or importance of kola nut. The Igbo use it to pray; the Yoruba produce it, while the Hausa consume it. Unity of purpose, trust, understanding and acceptance are very important for a nation that wants to move forward. USIP document $(2014: 22)$ retreat that a "Condition in which the population achieves a level of tolerance and peaceful co-existence; gains social cohesion 
through acceptance... has community institutions that bind society across divisions." Nigerians should therefore as a matter of urgency adopt the use of Igbo kola nut as a binding force. In the same manner it was observed that Igbo kola nut comes in more than two pieces sometimes four and seven in rare case. This shows that it can be used to bring the nation together and preach peace as well.

\section{Suggestion}

It would be advisable for Nigeria to adopt the social importance of kola nut and also serve it first at every event. If the meaning attached to Igbo kola nut be adopted, all the ethnic groups will forget their differences, find a common ground of reconciliation, accept each other; and see themselves as brothers. This will go a long way in bringing peace to the nation, since peace breeds progress.

Furthermore, if the lesson learnt on the manner in which Igbo kola nut is shared, is adopted by Nigerians; political imbalance, neglect, unfair treatment, marginalization which is found in the Nigeria politics will be a thing of the past. Igbo kola nut is a sacred seed that draws the attention of the unseen on the needs of his people; as they pray with it. This could also be adopted in Nigeria for peace talk, prayers of unity, forgiveness and togetherness.

It will also be advantageous to the nation if the unifying role exemplified in kola nut be adopted in the nation. Igbo kola nut has many lobes yet tied together as one. Igbo kola nut serves economic function as it is marketed and used in various ways. In the same way if Nigeria nation will adopt the plantation of kola nut in a large quantity, it will help to boost the Nigerian economy. 


\section{Conclusion}

Igbo culture is not complete without the custom of kola nut. Kola nut symbolizes peace, unity, hospitality, acceptance, togetherness, trust and equity. It performs a lot of functions, such as social, political, religious, economic and unifying functions. The importance of Kola nut has formed an integral part of all the ceremonies in Igbo land. People learn to accept each other, trust one another and have lived together in peace. Apakama (2012:41), quoting kaitholil (2009:8-9), states that peace is the deepest desires of every person... tranquility, the state of being undisturbed ,...harmony with oneself, one's brother and sister, one's world and one's God... healing of wounds, of hurt feelings, of hatred... sleep without fear, to have no enemies.

In as much as there were various groups that made up the nation and possible misunderstandings that might manifest as people come together; it is therefore, advisable for the government to adopt the unifying force of the Igbo kola nut for a well stable and unified nation.

\section{Ifeyinwa Cordelia Isidienu}

Department of Igbo, African and Asian Studies

Nnamdi Azikiwe University, Awka 


\section{References}

Apakama, L. M. (2012).'Igbo kola nut: its Socio-Cultural significance for Peace." In Alex A. O. Anedo \& Thecla N. Udemmadu. The Ideal Man. Awka. Apple Book Publishers. PP. $36-41$.

Ekhosuehi, A. (2015). "Kola nut in custom." Retrieved November,10, 2015, from www. edoworld. Net/kola.

Ekwealor, C. C. (1998). Omenala na Ewumewu ndi Igbo. Onitsha: Plama Publishers.

Ekwunife, A.N.O. (1990). Consecration in Igbo Traditional Religion: Enugu. Jet Publishers.

Ibeabuchi,O. M. (2013). "Metaphysics of kola nut: Towards an Authentic African Igbo communion; A Challenge to Christianity". Filosofia Theoretical: Journal of African Philosophy, Culture and Religion. CULLED FROM THE INTERNET

Igbo, P. C. (2012). Elements of Igbo Culture \& Tradition. Onitsha: Elite Publishers.

Kanu,I. A.(2015). A Hermeneutic Approach to African Traditional Religion. Jos: $\quad$ Augustinian Press.

Mayaki,V. O. (2011). "Kola Nut a True Symbol of our Culture". Retrieved November,10,2015, from www.igbofocus..co.uk/h NdiIgbo- Strategizing for the future.

Nwachukwu, M. (2015,September 3). “Kola nut: Nigeria's Seed of Togetherness". Retrieved October, 22, 2015 from www.Vangurdngr.com

Ogbalu, F. C. (2006). Igbo Institutions and Customs. Onitsha: University press.

Opata, D. U. (1998). Essays on Igbo World View. Nsukka: First Publishers. 
Orji, M. O. (!999). The History and Culture of the Igbo People before the Advent of the White Man Nkpor: Jet Publishers.

Osuji, C. (1998). Foundation of Igbo Tradition and Culture. Owerri: Opinion Research Publishers.

Ukaegbu, F. N. (2005). The Igbos; The Afrikan Root of Nations. Ibadan: Heinemann Educational Books.

USIP Document. "Social Reconstruction" Retrieved from http://www. Usip.org|publication|socialization. 19|4|2014. 